\title{
Survival and place of treatment after premature delivery
}

\author{
D Field, S Hodges, E Mason, P Burton
}

\begin{abstract}
In a one year prospective study in the Trent region we examined the short term outcome (survival to discharge) of all infants who required admission to a baby care unit. Infants of less than or equal to 28 weeks' gestation who received all their perinatal care in one of five large centres (each providing more than 600 ventilator days/year) showed significantly better survival rates than infants electively treated throughout their entire course at one of the 12 smaller units (34 survivors from 65 infants (52\%) compared with eight survivors from 37 infants (22\%). These differences occurred despite the elective transfer of many of the sickest infants from the smaller units to the larger. Differences in survival between more mature infants were not significant. These results support the policy that there should be a more centralised neonatal service for those infants at or below 28 weeks' gestation.
\end{abstract}

Neonatal intensive care is expensive, ${ }^{1}$ and potentially hazardous, ${ }^{2}$ but many paediatricians feel that it has made a considerable contribution to the improvements in perinatal and infant mortality in the last two decades. ${ }^{34}$ Others have reservations about the rapid growth of the specialty. 56

This controversy has arisen because the value of neonatal intensive care has never been tested in a controlled trial, and few clinicians would now consider that such a trial was ethical. Similarly, major treatment measures in neonatal intensive care (such as artificial ventilation for the idiopathic respiratory distress syndrome) have not been subject to controlled clinical trials in the last 20 years. Limited data supporting neonatal intensive care have been provided by studies reporting the effect of intensive care not being available when requested. ${ }^{7-9}$

This report examines how differing approaches to neonatal care, decided electively, affected survival after premature delivery in one region within the United Kingdom.

\section{Subjects and methods}

A one year prospective study was undertaken of all infants requiring admission to any of the baby care units in the Trent health region. Trent is the second largest of the United Kingdom health regions with a population of roughly 4.6 million and about 56000 births annually. There are 17 consultant obstetric units with associated infant care facilities. At the time of the study the baby units could be divided into two categories:firstly, there were five intensive care units which regularly carried out intensive care procedures such as artificial respiratory support, and secondly, there were 12 special care units with variable capacities for intensive care. The former group conformed to the guidelines of the Royal College of Physicians for either regional or subregional perinatal centres. ${ }^{10}$

All the large units had at least one consultant with an interest in neonatal medicine, all had 24 hour middle grade medical cover, and all ran specialist courses in neonatal nursing. Each unit carried out at least 500 days of ventilation annually (range 605-1590 days). Of the 12 smaller units four aimed to provide intensive care for most of the infants born in the hospital, and the remainder planned to transfer most cases needing intensive care. Most but not all of these units had a consultant with an interest in neonatal care, three had 24 hour middle grade medical cover (none resident on site), and none ran a course in neonatal nursing. Ten of the special care units had equipment available to provide long term artificial ventilation, the commonest intensive care procedure. None of the 12 units provided more than 500 days of ventilation annually (range $5-420$ days).

The study took place between 1 February 1987 and 31 January 1988. Data were collected on every admission to each of the 17 baby care units by one of four observers (two doctors and two nurses); we recorded place of booking, place of birth, birth weight, gestation, treatment, and outcome (discharge or death).

No infant referred for intensive care was refused, although on 14 occasions this required transfer outside the region. Policy in all 17 units ensured the admission of most infants of less than 34 weeks' gestation and all infants of less than 32 weeks' gestation.

\section{ANALYSIS}

Categorical data were analysed using contingency tables and the $\chi^{2}$ test with correction for continuity. In those instances where the expected number in any one cell was less than 5 , Fisher's exact test was used and a one tailed p value is quoted. When the data were not normally distributed the Mann-Whitney test was used. Confidence intervals (C1) for the relative odds were estimated by exponentiation of the confidence intervals of the logit. ${ }^{11}$

Results

During the study there were 4252 admissions of
Correspondence to:

Accepted 12 December 1990 
Table 1 All babies studied according to where they received their perinatal care, gestational age, and mortality

\begin{tabular}{|c|c|c|c|c|}
\hline Group & $\begin{array}{l}\text { All perinatal } \\
\text { care in } \\
\text { large units }\end{array}$ & $\begin{array}{l}\text { All perinatal } \\
\text { care in } \\
\text { small units }\end{array}$ & $\begin{array}{l}\text { Antenatal } \\
\text { transfers to } \\
\text { large units }\end{array}$ & $\begin{array}{l}\text { Postnatal } \\
\text { tranfers to } \\
\text { large units }\end{array}$ \\
\hline $\begin{array}{l}\text { All admissions: } \\
\text { Total No } \\
\text { No }(\%) \text { deaths }\end{array}$ & $\begin{array}{l}1443 \\
95(7)\end{array}$ & $\begin{array}{l}2500 \\
77(3)\end{array}$ & $23(20)$ & $\begin{array}{l}192 \\
46(24)\end{array}$ \\
\hline $\begin{array}{l}\text { Babies of }>32-\leqslant 34 \text { weeks' gestation } \\
\text { Total No } \\
\text { No (\%) deaths }\end{array}$ & $\begin{array}{l}268 \\
4(2)\end{array}$ & $\begin{array}{l}345 \\
5(2)\end{array}$ & $\begin{array}{l}17 \\
1(6)\end{array}$ & $\begin{array}{l}28 \\
5(18)\end{array}$ \\
\hline $\begin{array}{l}\text { Babies of }>30-\leqslant 32 \text { weeks' gestation } \\
\text { Total No } \\
\text { No (\%) deaths }\end{array}$ & $\begin{array}{l}174 \\
9(5)\end{array}$ & $\begin{array}{l}170 \\
11(6)\end{array}$ & 30 & 31 \\
\hline $\begin{array}{l}\text { Babies of }>28 \leqslant 30 \text { weeks' gestation } \\
\text { Total No } \\
\text { No }(\%) \text { deaths } \\
\text { Babies of } \leqslant 28 \text { weeks' gestation }\end{array}$ & $\begin{array}{l}97 \\
17(18)\end{array}$ & $\begin{array}{l}30 \\
2(7)\end{array}$ & $8(42)$ & $\begin{array}{l}25 \\
9(36)\end{array}$ \\
\hline $\begin{array}{l}\text { Total No } \\
\text { No }(\%) \text { deaths }\end{array}$ & $\begin{array}{l}65 \\
31(48)\end{array}$ & $\begin{array}{l}37 \\
29(78)\end{array}$ & $\begin{array}{l}35 \\
14(40)\end{array}$ & $\begin{array}{l}47 \\
19(40)\end{array}$ \\
\hline
\end{tabular}

infants born inside the region. These were divided into four groups: babies who received all their perinatal care in one of the five hospitals with full intensive care facilities, those who received all their perinatal care in one of the 12 hospitals not designated as having full intensive care facilities, those transferred antenatally from a small hospital to a large hospital, and those transferred after delivery from a small hospital to a large hospital. The distribution by gestational age and survival of infants in the four groups is shown in table 1.

Comparing infants treated in the large hospitals with those treated in the small ones, several points arise.

Survival among all admissions (irrespective of gestational age) was apparently better for infants in the smaller units. This is not an appropriate comparison, however, because the special care units operated a completely different admission policy that lead to the admission of a large number of mature infants for treatments other than intensive care (infants $>34$ weeks' gestation, no intensive care: larger units $756,56 \%$ of all admissions; smaller units 1864 , $77 \%$ of all admissions). An increased number of lethal malformations was also included in the deaths on large units (33 compared with 24). Other malformations that required operation carrying a high mortality (for example, diaphragmatic hernia) were transferred out of the small units and are included in columns 3 and 4 of table 1 .

Survival of infants of $>32$ but $\leqslant 34$ weeks' gestation, $>30$ but $\leqslant 32$ weeks' gestation, and $>28$ but $\leqslant 30$ weeks' gestation was not significantly different between the two types of unit $(p=0.65,0.77$, and 0.12 , respectively, Fisher's exact test). Relative odds ( $95 \% \mathrm{Cl}$ ) of dying (small units compared with large units) in these gestational age groups were:0.97 (0.25 to 3.70$)$, $1.26(0.50$ to 3.23$)$, and $0.34(0.07$ to 1.61$)$, respectively.

Survival of infants $\leqslant 28$ weeks' gestation was significantly better for infants treated in designated intensive care units ( 34 survivors from 65 infants compared with eight survivors from 37 infants, $\chi^{2} 7.94,1 \mathrm{df}, \mathrm{p}<0.005$; relative odds $(95 \% \mathrm{Cl})$ of dying (small units compared with large units) were $3.98(1.55$ to 10.18$)$ ). Improved survival was not related to an excess of congenital abnormalities among infants in special care units.
In addition, the two groups of infants were compared with a scoring system designed to predict outcome based on the following variables: birth weight, gestation, respiratory distress at birth, cephalic or breech presentation, Apgar scores at 1 and 5 minutes, and multiple pregnancy. ${ }^{12}$ The most important components of this score are respiratory distress at birth, birth weight, and Apgar score at 5 minutes. Only the incidence of respiratory distress was significantly different between the two types of unit indicating a worse potential for infants from larger units. Large units had 62 of 65 with respiratory disease compared with small units that had 28 out of $37, \mathrm{p}<0.01$; mean (SD) birth weight in large units was $970(26) \mathrm{g}$ and in small units 930 (28) g, p>0.05; and mean (SD) 5 minute Apgar scores in large units were 7 (2), range $1-10$ and in small units $6(3)$, range $1-10$, $p>0.05$. There were no significant differences between any of the other variables.

Despite being particularly high risk groups (confirmed by risk scoring) infants of $\leqslant 28$ weeks' gestation who were transferred either antenatally or postnatally to large units showed improved survival compared with infants who remained in special care nurseries. Antenatal transfers $\leqslant 28$ weeks' gestation: 21 survivors from 35 infants compared with eight survivors from 37 infants, $\chi^{2}=9.48,1 \mathrm{df}, p<0.002$; relative odds of dying $(95 \% \mathrm{Cl})$ (transferred compared with not transferred 5.44 (1.89 to $15 \cdot 62)$. Postnatal transfers at $\leqslant 28$ weeks' gestation: 28 survivors from 47 infants compared with eight survivors from 37 infants, $\chi^{2}=11 \cdot 31$,

Table 2 Babies who received all their perinatal care in large or small units divided according to birth weight and mortality

\begin{tabular}{lll}
\hline & $\begin{array}{l}\text { All perinatal } \\
\text { care in } \\
\text { large units }\end{array}$ & $\begin{array}{l}\text { All perinatal } \\
\text { care in } \\
\text { small units }\end{array}$ \\
\hline $\begin{array}{ll}\text { All babies } \\
\text { Total No }\end{array}$ & 1443 & 2500 \\
$\begin{array}{c}\text { No (\%) deaths } \\
\text { Babies weighing 2000-2500 g } \\
\text { Total No }\end{array}$ & $95(7)$ & $77(3)$ \\
$\begin{array}{c}\text { No (\%) deaths } \\
\text { Babies weighing 1500-2000 g }\end{array}$ & 289 & 603 \\
$\quad \begin{array}{l}\text { Total No } \\
\text { No (\%) deaths }\end{array}$ & 295 & $10(2)$ \\
$\begin{array}{c}\text { Babies weighing 1000-1500 g } \\
\text { Total No }\end{array}$ & $7(2)$ & 955 \\
$\begin{array}{c}\text { No (\%) deaths } \\
\text { Babies weighing <1000 g } \\
\text { Total No }\end{array}$ & 146 & 90 \\
No (\%) deaths & $58(14)$ & $11(12)$ \\
\hline
\end{tabular}


$1 \mathrm{df}, \mathrm{p}<0.0008$; relative odds of dying $(95 \% \mathrm{Cl})$ (transferred compared with not transferred) $5.34(1.97$ to $14 \cdot 45)$.

Reviewing the same data by birth weight shows the same trends, but differences in survival are not significant (table 2). This is to be expected as in general mature growth retarded infants do well without the severe problems related to immaturity. Some of these infants will have been included in the low birthweight groups.

\section{Discussion}

These data indicate that infants of 28 weeks' gestation or less show improved survival when they are treated in recognised neonatal intensive care units compared with infants who are electively treated in smaller units. This difference is particularly important, as many of the sickest infants were transferred from the smaller units and this was confirmed by risk scoring. There was no indication that the smaller units electively retained an excess of infants unlikely to survive for terminal care. It was in the larger units that a policy of offering terminal care to very immature infants away from the labour ward was more firmly established. The mechanism for the improved survival has not been shown.

No information is available about rates of handicap. Clearly this is important and will be considered in a further study. The limited number of survivors of 28 weeks' gestation or less, however, means that a study of several health regions will be required to obtain sufficient data for comparison. Without these data our findings must be interpreted with caution.

In a recent publication that was broadly critical of neonatal intensive care, attention was focused on artificial respiratory support as the essential element. ${ }^{6}$ This seems inappropriate as many aspects of perinatal care have evolved in the last 20 years to produce what we now call neonatal intensive care. Any advantages that large centres have are likely to relate both to obstetric and neonatal experience with high risk deliveries rather than individual treatments. The growth and dissemination of knowledge in neonatal care has clearly produced good short term survival figures for infants of more than 28 weeks' gestation in all units.

These findings are of importance in the futures planning of neonatal care. Although centralisation of neonatal care has been advocated there has been no direct evidence to support such a move in the United Kingdom, ${ }^{10}$ although data similar to our own are available from the United States and The Netherlands. ${ }^{13} 14$ Our data indicate that survival of infants of $\leqslant 28$ weeks' gestation is better when they are cared for in designated centres. It seems unlikely that future studies will be able to separate the differences in contributions of medical care (obstetric and neonatal), nursing care (neonatal and midwifery) and type of equipment between the two types of unit in a controlled manner. Based on the criteria of improved survival alone, therefore, these findings indicate that the intensive care of infants delivered at $\leqslant 28$ weeks' gestation and the perinatal care of pregnancies identified as high risk should be concentrated in units: that carry out at least $\mathbf{5 0 0}$ days of neonatal ventilation/year; that have at least one consultant with a special interest in the newborn, and that have continuous middle grade medical cover; that have a high level of nursing expertise and training in neonatal care; and where obstetric care for high risk deliveries is well established.

For infants of more than 28 weeks' gestation there is no indication from these data that care should take place in designated centres. A comparison between the two types of unit of these more mature babies with similar diseases has not been possible. This might be achieved in a study of several regions that would provide sufficiently large numbers to allow matching for severity of disease.

We thank all the perinatal units in the Trent region without whose help this work would not have been possible. The study was funded by the Trent Regional Health Authority.

1 Newns B, Drummond MF, Durbin GM, Culley P. Costs and outcomes in a regional neonatal intensive care unit. Arch Dis Child 1984;59:1064-7.

2 Haas R, Davies PA. Iatrogenic hazards in the newborn intensive care unit. In: Wharton B, ed. Topics in perinatal medisive care unit. In: Wharton B, ed. Topics in perinatal medi-

Powell TG, Pharoah POD, Cooke RWI. Survival and morbi-

dity in a geographically defined population of low birthdity in a geographically defined popul

4 Speidel B. Skimping on care of the newborn is false economy. $B M F$ 1986;293:575-6.

5 Steiner ES, Sanders EM, Phillips ECK, Maddock CR. Very low birthweight children at school age: comparison of neonatal management methods. $B M \mathcal{F}$ 1980;281:1237-40. 6 Maddock CR. A population-based evaluation of sustained mechanical ventilation of newborn babies. Lancet 1987;ii: 1254-8.

7 Sims DG, Wynn J, Chiswick ML. Outcome for babies declined admission to a regional neonatal intensive care unit. Arch Dis Child 1982;57:334-7.

8 Roper HP, Chiswick ML, Sims DG. Referrals to a regional neonatal intensive care unit. Arch Dis Child 1988;63:403-7.

9 Harmini S, Heasly RN, Patterson CC, Halliday HL, Thompson W. Short term outcome in babies refused periThompson W. Short term outcome
natal care. $B M \mathcal{F} 1989 ; 299: 647-9$.

10 Royal College of Physicians. Medical care of the newborn in England and Wales. London: Royal College of Physicians, England 1988 .

11 Breslow NE, Day NE. Statistical methods in cancer research. The analysis of case control studies. Vol 1. Scientific Publication No 32. Lyon: International Association for Research on Cancer, 1980.

12 Patterson CC, Halliday HL. Prediction of outcome after delivery for the very low birthweight $(<1500 \mathrm{~g})$ infant. Paediatric and Perinatal Epidemiology 1982;2:221-8.

13 Paneth N Kiely JL, Wallenstein S, Marcus M, Pakter J, Susser M. Newborn intensive care and neonatal mortality in low-birth-weight infants. Population study. $N$ Engl 7 Med 1982;307:149-55.

14 Verloove-Vanhorick SP, Verwey RA, Ebeling MCA, Brand $\mathrm{R}$, Ruys JH. Mortality in very preterm and low birthweight infants according to place of delivery and level of care: results of a national collaborative survey of preterm and 1988;81:404-11.

\section{Commentary}

Provision of neonatal intensive care has been singled out by the Royal College of Physicians and the National Audit Office as an area for improvement in services, ${ }^{2}$ and the chief executive of the NHS has made it a priority for regions and districts to review their maternity and neonatal services with a view to further reductions in mortality. ${ }^{3}$ Between 1980 and 1986 , in England, the number of cots for neonatal intensive care more than doubled, and birthweight specific perinatal and neonatal mortality fell in all categories of birth weight. 